\title{
O Mito do Sacrifício na Cruz
}

Maria José de Queiroz

A história, como sabemos, alimenta-se de mitos. Há mitos e mitos. . Para Roland Barthes, por exemplo, "o mito é um sistema de comunicação, é uma mensagem". ${ }^{1}$ Tal definição encarece a importância do meio escolhido, sem referência ao alvo, ou fim, a que se destina. E, convém, parece-nos, considerá-lo com cuidado a fim de melhor apreciar a repercussão da mensagem transmitida.

Socorra-nos agora o episódio da crucifixão de Patrick e Maritza Tamao, da República Dominicana, divulgado há algum tempo pela imprensa: ${ }^{2}$ após vinte e quatro horas de permanência na cruz, Patrick se fez substituir pela mulher, Maritza, que logrou prolongar o sacrifício por cinqüenta e duas horas. Como toda mitologia se vincula a um fundamento histórico, o gesto dos Tamao cumpriu, eficazmente, a sua função: a de recuperar, para uso profano, o mito da redenção pelo sacrifício da cruz. Não se busque, porém, na mensagem proposta - "que se submetiam ao martírio em favor da paz mundial" - o verdadeiro interesse do episódio. Crisma-o, exaltadamente, o conceito da imolação, encarecido pela deliberada

1. «Le mythe, aujourd'hui», in Mithologies. Paris, Editions du Seuil, 1957 , p. 193.

2. Eis o que se lia, à guisa de legenda à fotografia do casal: «Muito abatido e com uma infecção no pé (ele), um pouco pálido e febril (ela), assim ficaram Patrick e sua mulher, Maritza Tamao, ao se deixarem crucificar, cada um de uma vez, como Jesus Cristo.

- Nosso sacrificio, disseram, foi a favor da paz mundial...» (UPI, Santo Domingo, fevereiro de 1973). 
escolha da cruz, instrumento mítico de mundificação. Graças a ela acedemos ao domínio das mitologias onde a palavra se converte em imagem e símbolo.

Barthes, já citado, nega a existência de objetos fatalmente sugestivos, contrariando, entre outros, a Baudelaire. A história parece conspirar contra o crítico francês, em abono do poeta de Les fleurs $d u$ mal. Os objetos fatalmente sugestivos intrometem-se hoje na nossa vida diária, tomam de assalto as páginas dos jornais. Avulta entre todos o símbolo de validade universal, propício a toda mensagem de paz, amor e sacrifício - a cruz. Nesse caso, a mera designação do objeto anuncia o verbo mítico. Verifica-se, por conseguinte, a perfeita síntese significativa, ainda que à míngua de voz e legenda. Basta a imagem do crucificado para que se chegue à apreensão do código. ${ }^{3}$

O conteúdo mítico do amor, hoje expresso no slogan "Make love don't make var", promove a cena de Santo Domingo a espetáculo, transforma-a em notícia. Confere-lhe sentido religioso, político e, até mesmo, ideológico. O mito adquire, então, valor positivo: é libelo. Protesto. O que não impede, no entanto, se veja nele o álibi ideal do suicídio e, também, a consagração pública do heroísmo, mercê do martírio.

Respondendo à dialética do sacrifício e da salvação, da morte e da vida, da guerra e da paz, os Tamao repetem, como personagens, o drama do Gólgota. O seu gesto alienado, apesar do denso conteúdo dramático, nada tem de revolucionário. Apesar de todo o seu esforçado empenho... Refugiados na sua fragilidade humana, o casal pretende ascender à condição do herói, do mártir, do santo. Aspiram ambos, parece, à sacralização do sacrifício que proclama: urbi et orbe, a pureza das suas intenções, a sua abnegação, a sua solidariedade efetiva. Ipso facto, é força intuí-lo, o martírio realça a vilania de quantos assistem, indiferentes, à maldade, à injustiça, à morte. E, conclusivamente, à crucifixão dos dois pobres inocentes. Logo, de vítimas, ou sacrificados, ei-los,

3. $\$$ o caso, por exemplo, de «Doia na janela» conto de ROBERTO DRUMMOND (A morte de D.J. em Paris. Sāo Paulo, Editora Ātica, p. 21-25), cuja protagonista, louca, assiste à noite, da janela, à cricifixão de um Cristo que se parece com Alain Delon. 
diante de nós, como testemunhas de acusação, fonte de crítica, espelho de ímpios. Pascal iria mais longe. Havia de denunciar-lhes o desmedido orgulho, claramente manifesto no desejo de ser deus.

Esse gênero de tentação, a tentação do sacrifício por amor à humanidade, difere da tentação do heroísmo assanhado porque se reveste de humildade a fim de copiar a mansa e sublime vocação do Cristo. Como o seu reino, nas suas próprias palavras, não é deste mundo, aqueles que com ele se identifiquem eximem-se facilmente de qualquer responsabilidade de compromisso com interesses criados. A ausência de resposta, o silêncio, a indiferença pouco significam. Talvez mesmo, num recurso ao absurdo, cheguem a instigar ao sacrifício. Na gratuidade do ato consagra-se o desprendimento da vítima ao mesmo tempo que autoriza a crítica altiva à humanidade. $\overline{\mathrm{E}}$ verdade. Do alto da cruz, os Tamao nos contemplam. Au-dessus de la mêlée.

A história, devoradora de mitos, é, por outro lado, responsável pela sua memória e perenidade. Depois de consumi-los, recupera-os como valores. Assim, o mito empolga impunemente a realidade, furta sucessos, encobre êxitos, arrebatando pormenores, acidentes e datas. A verdade torna-se, sob o seu império, presa submissa. No entretanto, o significado nuclear do mito permanece intacto: o que varia é o acessório, sujeito, constantemente, a novas interpretações. Ã luz da inteligência, ao saber de variada índole, ele poderá servir, indistintamente, à paz ou à guerra, ao amor ou ao ódio. A vida, tanto quanto a ficção, encarrega-se de adaptá-lo às mais diferentes circunstâncias. Para isso basta, apenas, grifar-lhe a mensagem. Nos seus signos excessivos, ou na iconografia espetacular.

Em resposta a diferente intuito, podemos avaliar, na literatura, no cinema, no teatro, a eficácia do mito do sacrifício na cruz, em modelos semelhantes ao da "representação" do drama do Calvário da República Dominicana. Integrados no mesmo sistema mítico, de múltipla simbologia, movem-se os seus protagonistas no palco do imaginário, ao qual também poderíamos chamar "o grande teatro do mundo".

Vejamos: no cinema, ao modo e estilo de Jules Dassin, tivemos Celui qui doit mourir. O diretor procura ressaltar no filme a 
necessidade do sacrifício em obediência estrita à tradição. O Cristo recrucificado (1954), tal como o viu Katzanzakis, cumpre, uma vez mais, a sua missão redentora, mediante o assentimento e a aprovação de todos os fiéis. No teatro brasileiro, a reinterpretação do tema por Dias Gomes oferece-nos um Cristo malgré lui. Sacrificado por equívoco. Resgata-o da infâmia a apoteose final: entroniza-se na igreja, carregado pelo povo, braços e mãos abertos sobre a cruz.

$\mathrm{Na}$ atual novelística hispano-americana, temos excelente exemplo no romance de Rosario Castellanos, Oficio de tinieblas. Introduz-nos a escritora mexicana, ao modo indígena, na interpretação da profecia bíblica do nascimento, paixão e morte do Messias. ${ }^{4}$

Numa aldeia perdida do México, no vale de Chamula, a índia Catalina inicia nos mistérios da cruz o filho eleito para o sacrifício cruento. Domingo Díaz Puiljá - "o que nasceu durante o eclipse" -, submisso à vontade divina, deve ser vítima e testemunha da própria execução. Pregado à cruz, os cravos atravessam-lhe os ossos, perfuram-lhe as carnes, penetram-lhe a pele, rasgam-lhe os tendões. O seu suplício, repete, em via sacra, a crucifixão de Cristo: começa pela funda ferida que sangra - "del costado, como en todas las crucifixiones".5 "Com um sorriso de placidez Domingo perde o conhecimento". 6 Para desespero da própria mãe, que deseja, como todos, que o menino venha " $a$ ser la víctima pero también el testigo, de su propia ejecución".7 Ao voltar a si, Domingo se presta à obra de extermínio. Cumpre-se solenemente, em dor, lamento e muito sangue, o desejado sacrifício: "La sangre continúa fluyendo pero ya no en borbotón ni en torrente. Gotea. Y cada gota es recibida abajo por los paños finisimos de las madrinas del sacramento que los tiñe de rojo. Lo que escurre a lo largo de la madera es lamido por los mayordomos, por el sacristán, por Catalina".8
4. México, Editorial Joaquín Mortiz, 1962.
5. Livro cit., p. 321 .
6. Id. ibid., p. 322 .
7. Id. ibid., p. 323.
8. Id. ibid., p. 323. 
Consumadas a paixão e morte do pequeno chamula, os índios rejubilam-se: "Agora também temos um Cristo. Não nasceu em vão nem agonizou nem morreu em vão. Seu nascimẹto, sua agonia e sua morte servem para nivelar o tzotzil, o chamula, o índio, com o ladino. Por isso, se o ladino nos ameaça devemos fazer-lhe frente e não fugir. Se nos persegue devemos enfrentá-lo cara a cara".9

Os brancos - ladinos, possuidores do Cristo e dos privilégios do Cristianismo, prevaleciam-se dessa superioridade para negar aos índios a salvação eterna e mais prerrogativas de aquém e alémtúmulo. Apenas as concediam aos que, em bom e castiço castelhano, soubessem recitar o Pai-Nosso. À alegação de que Deus, o Onipotente, lhes entregara as tábuas da lei, proclamavam-se divulgadores e únicos detentores da verdade. Visto caber-lhes, e a eles somente, o uso e posse do Filho de Deus, não restava aos chamulas, de língua tzotzil, senão este recurso - o de criar o seu Cristo, à imagem e semelhança do seu Deus. Assim fizeram.

A agonia e crucifixão de Domingo corrigiram o engano da Igreja católica. A sua morte diminuiu a distância entre opressores e oprimidos. Catalina justificou o prolongado castigo imposto ao filho afirmando que a sua alma vegetal e obscura carecia das graças exigidas pelas potências divinas. Porque índio, e rude, o seu sacrifício deveria ser mais penoso que o do Cristo judeu.

Depois da lenta consumação, a divindade se manifesta. o Salvador da raça humilhada entrega a alma. O seu grito ressoa até o "último rincão da zona habitada pelos tzotziles". Estava concluída a sua missão. A tribo pôde, finalmente, ascender à dignidade do batismo: "Sobre nossas cabeças caiu o sangue do batismo". E os que são batizados com sangue, e não com água, está dito que não morrerão".10

Sonho exaltado, de origem messiânica, que se confunde com a mítica da cruz e com a tentação da divindade. O século XVII talvez o considerasse como um exagero do "amor-próprio". Pascal,

9. Id. ibid., p. 324 .

10. Id. ibid., p. 324 . 
que nos Pensamentos atacou rijo a insensata vaidade dos homens, desejosos de desempenhar o papel de Deus, haveria de exclamar - "O ridicolosissimo éroe!" 11

A anedota, que motivou a nossa divagação acerca dessas variações em torno do tema da cruz, pode ainda levar-nos a uma observação: a de que muito raramente cabe à mulher o exercício desse gênero de heroísmo. O único caso em que a realidade superou a ficção, em gesto de coragem, foi o de Joana D'Arc. A sua história foge a todo sistema, exigindo nova e diferente interpretação do mito. No que tange à formação de pares, ou mesmo de grupos masculinos, não nos faltam exemplos de fácil lembrança: Roland e Olivier, os quatro filhos de Aymon, o Couraçado de Potemkine (heroísmo coletivo) etc. etc. Agora, o insólito: Patrick e Maritza inauguraram, na cruz, uma forma de companheirismo conjugal ignorada. Mas... ressalve-se: a morte não lhes sacralizou o sacrifício. Estamos portanto longe do mito e das suas epifanias.

11. PASCAL, Pensées (II, «Vanité»), in Oeuvres complètes. Par1s, Editions du Seuil, 1963, p. 506. 